\title{
Inblickar i revolutionärernas Europa
}

Recension av Peter Kadhammar, Vi som var så lyckliga. Liv och död $i$ en kommunistisk diktatur (Natur \& Kultur, Stockholm 2017) \& Victor Klemperer, Revolutionsdagbok I9Ig. Skratta och gräta på samma gång (Fischer \& Co, Stockholm 2016)

\section{ANDERS BJÖRNSSON}

Sommaren 1969 gjorde jag en två veckors turistresa till Albanien. Samtidigt förberedde jag ett specialarbete i gymnasiets sista årskurs om den bayerska rådsrepubliken våren 1919. Münchenrepubliken sköts sönder och samman i en masslakt, på befallning av den tyska riksregeringen och med villigt bistånd av högerextrema frikårer, vad som i dag skulle kallas terrorister. I Tirana satt femtio år senare en regering av före detta partisaner, vars medlemmar tyckte om att avrätta varandra.

Alla aktörerna - I919 som 1969 - hade upplevt ett blodigt världskrig och tagit både intryck och skada av det. Det väpnade våldet utgjorde en naturlig komponent i deras sociala miljöer; politik utan strid och eliminering av motståndaren var någonting otänkbart och $\mathrm{i}$ viss mening också straffbart. Om det dödliga våldet efter första världskriget merendels utlöstes av högerkrafter, var det den politiska vänstern som var mest våldsbenägen efter andra världskriget. I båda fallen fanns det hämnd att utkräva.

Min mission i Albanien var egentligen politisk. Jag satt en kort stund i ledningen för Vänsterns ungdomsförbund, Anders Carlbergs verkställande utskott, och tillsammans med ett par kamrater skulle vi försöka upprätta reguljära kontakter med Albanska arbetets parti, som var det styrande och enda tillåtna partiet i denna balkanska stat med höga berg och vackra Medelhavsstränder. Det var ett led i den egna linjekampen, i en anti-Moskva-linje. Försöket misslyckades kapitalt. Andra hade varit före. 
$\mathrm{Nu}$ blev besöket inte utan följder. Jag skrev mitt specialarbete om die Räterepublik och kom att intressera mig mer och mer för den albanska kulturen, litteraturen och politiken. Albanien var, tillsammans med Jugoslavien, det enda östland där de statsbärande kommunisterna hade gripit makten på egen hand, som resultat av ett folkligt befrielsekrig riktat mot tyska och italienska ockupanter. Genom Ismail Kadares böcker kom man både historien och samtiden nära. En av hans senare romaner, Pasardhësi ("Efterträdaren", ej översatt till svenska, på franska utgiven som Le successeur 2003), läste jag långt efter det att det albanska samhället hade kommit på betryggande avstånd och inte utövade någon lockelse, vare sig i dess tidigare eller i dess nyare form.

Peter Kadhammar har läst det mesta av Kadare, den före detta nationalförfattaren, och det är lätt att föreställa sig att just Pasardhësi har varit en inspirationskälla för honom när han påbörjade arbetet med sin nya bok. Kadare skildrar där de mörka omständigheterna kring Mehmet Shehus plötsliga bortgång 198I. Shehu var premiärminister och nummer två i hierarkin efter partiets ledare Enver Hoxha. Alla utgick från att han skulle efterträda den utslitne och diabetessjuke Hoxha. I stället försvann han, anklagad för att vara agent åt främmande makt, i första hand ärkefienden Jugoslavien.

Hos Kadare fick man en klar föreställning om de politiska och privata förhållandena inom den lilla maktcirkeln, som alla bodde inom ett mycket litet, avspärrat område i huvudstaden, "Kvarteret", och ofta även semestrade tillsammans. Kadhammar har tjugofem år efter systemkollapsen och trettiofem år efter Shehus plötsliga död intervjuat sig fram bland de överlevande, de högsta hönsen lika väl som deras medarbetare och tjänstefolk. Intervjuerna är skickligt återgivna och det material som presenteras i Vi som var så lyckliga håller minst lika hög litterär kvalitet som Svetlana Aleksijevitjs rapportböcker. Det finns också, paradoxalt nog, ett stråk av Jan Myrdal i denna skildring, även om den senares reportage från den kinesiska fattigbyn i början av 6o-talet gav segrarnas version av ett förlopp och Kadhammar nu ger förlorarnas.

Han låter dem tala. De ger honom precisa uppgifter, han får av dem pregnanta formuleringar. De flesta han språkar med kommer från ett förutvarande privilegierat skikt, men i ekonomiskt hänseende kan de 
ingalunda betraktas som någon överklass: det socialistiska Albanien var ett samhälle med extremt låg Gini-koefficient. För att behålla sin ställning måste man vara försiktig, och denna försiktighet impregnerade i hela folket en stor rädsla. Utrymmet för linjekamp, för att inte tala om dissens var minimalt. Utrensningar var regelbundet förekommande och drabbade ofta dem i ledande positioner. Maktnätverken var så tätt vävda, befolkningen så fåtalig att nepotism och en modern form av blodshämnd hela tiden gjorde sig gällande på ett eller annat sätt. Människor blev uttröttade av sin egen misstänksamhet, inte att undra på.

Efter Kadhammars undersökning står det nu klart bortom tvivel att Shehu, premiärministern, visserligen blev utsatt för hårda interna angrepp men att han inte avrättades. Han begick självmord. Hans brott var att han hade tillåtit en av sina söner att förlova sig med en flicka från den gamla borgerliga klassen, ur en före detta "rik" familj. Det var oförlåtligt, fläckade den nya elitens anseende och utgjorde ett dåligt föredöme för det uppväxande släktet. Shehu, som annars tillhörde de strängaste och mest doktrinära inom partibyråkratin, hade begått en obegriplig blunder, men genom självmordet lurade han sina kamrater på att bli utsatt för förnedring.

Alla revolutioner skördar offer, även om de inte behöver omkomma i partisanstrider, gatuslagsmål och maktkomplotter, och hämndmotiv materialiseras även under i övrigt civiliserade förhållanden. Victor Klemperer, romanisten och dagboksförfattaren, blev ögonvittne till det revolutionära och det mera svårartade kontrarevolutionära våldet i den bayerska huvudstaden några månader efter första världskrigets slut. Han antecknade, skrev tidningsreportage (av vilka flera aldrig flöt in på grund av störda kommunikationer); under nästa krig skrev han ned sina minnen från denna hektiska tid. Allt (även det som inte blev publicerat) är nu utgivet i en behändig volym, Revolutionsdagbok I9I9. Skratta och gràta på samma gång. Ja, om jag hade haft tillgång till detta ...

Victor Klemperer skriver både lärt och medryckande, det vill säga han förmedlar mycken kunskap och styrs av ett engagemang som lika mycket är vetenskapsmannens som journalistens - det var först längre fram i tidningshistorien som de vände varandra ryggen. Själv jude märker författaren hur judarna redan nu börjar få skulden för "det röda tyranniet". Och 
det är i denna stads förnäma salonger som Adolf Hitler kort senare skulle nå sina första politiska framgångar.

Så här noterar Klemperer i sin revolutionsdagbok från april I9ı9:

En sak måste man med beundran tillstå om den nya [råds]regeringen: den ger staden en synnerligen krigisk prägel, den förstår att "imponera" på befolkningen, ja den förstår att hjälpa likformigheten i den sedan månader närmast långtråkiga revolutionsbilden på de något druckna, vingliga benen med hjälp av nya kraftiga färger. Att det strejkas behöver självfallet inte nämnas. Men vi har också väggplakat om att borgarna "vid dödsstraff" måste lämna in sina vapen inom I2 timmar. Och vi har i ständigt ökande antal beväpnade civilister, klassmedvetna, med bössan på ryggen - emellanåt rentav kvinnliga. Och militären! Infanterister och matroser marscherar tillsammans, eller rättare sagt: spatserar huller om buller. Geväret hänger, med mynningen neråt, kokett i remmen; om halsen och ner till livremmen hänger dinglande fältgråa halsdukar med instoppade laddramar, i livremmen bär man tre fyra långskaftade handgranater, kring armen röda bindlar. Det ser mer ut som vilda västern än München - och sedan ändå München: Texas efter skisser av Gulbransson.

De efterföljande slutstriderna blev rasande, ”och kommunisternas förtvivlade motstånd överträffade all förväntan”, antecknar Klemperer den Io maj. Det politiska dramat har framstått för honom nästan som ett skådespel - många revolutionärer var bohemer, intellektuella, tidningsredaktörer, pjäsförfattare - och då av det tragikomiska slaget. Han slutar sin dagbok med en begreppsdefinition: "tragiskt för den drabbade och komiskt för den ointresserade åskådaren. Så synd att man inte kan vara enbart åskådare när man är tysk.”

Egentligen uppehöll sig Klemperer i München för att främja sin akademiska karriär; samtidigt sände han en strid ström artiklar till Leipziger Neueste Nachrichten. Redan året därpå fick han en kallelse till en professur vid Tekniska högskolan i Dresden, en befattning som han behöll till 1935, då Hitlerregimen drev bort honom. Under Tredje riket studerade han det nazistiska språket och skrev dagböcker som blev en sensation när de gavs ut långt efter hans död 1960. Klemperer klarade sig mirakulöst nog i staden ända fram till krigsslutet, bland annat därför att han var gift med en "arisk" kvinna.

Efter Hitlers krig fortsatte han sin gärning i den socialistiska tyska statens tjänst. Även de dagböcker han då förde har betydande historiskt 
BJÖRNSSON | REVOLUTIONÄRERNAS EUROPA

intresse, inte minst genom de inblickar de ger i den östtyska nomenklaturans sätt att leva och resonera. De är också utgivna men väntar ännu på sin svenska översättning. 


\section{Rosa Luxemburg}

Rosa Luxemburg (1871-1919) var en egen och fri röst i den tidiga arbetarrörelsen - en slagfärdig stilist, mästerlig polemiker och hängiven revolutionär. Hennes liv och verk röner idag förnyat intresse.

Arkiv förlag har i tre volymer samlat hennes mest berömda politiska texter.

\section{Reformpolitik och socialism}

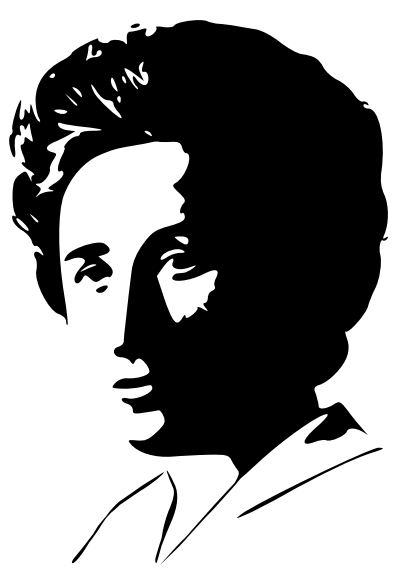

Politiska skrifter $i$ urval 1894-1913

Den första volymen innehåller den kända kritiken av Eduard Bernsteins revidering av marxismen och ett representativt urval av Luxemburgs politiska författarskap före första världskriget.

2:a uppl. 2017, 144 s.

\section{Masstrejk, parti och revolution}

Två uppsatser om arbetarrörelsens organisationsformer 1904-06

Den andra volymen sammanför Luxemburgs utan tvekan mest originella bidrag till marxismens politiska teori, "Masstrejk, parti och fackföreningar”, med hennes berömda angrepp på Lenins organisationsteori i "Den ryska socialdemokratins organisationsfrågor". 2:a uppl. 2017, 118 s.

\section{Världskriget och de europeiska revolutionerna}

Politiska skrifter $i$ urval 1914-19

Den tredje volymen täcker den dramatiska perioden från första världskrigets utbrott till Luxemburgs död 1919. Hon framträder här i tre roller: som kritiker av socialdemokratins ställningstagande till kriget, som kritiker av den ryska revolutionen och som ledare och inspiratör för vänsterflygeln i den tyska revolutionen. 1:a uppl. 1985, 192 s. 